\title{
Assemblage thinking in urban studies: how to conceive of a city?
}

\author{
HOLUBEC Pavel ${ }^{1, a^{*}}$ \\ ${ }^{1}$ CTU in Prague, Fac. of Civil Engineering, Thákurova 7, 16629 Praha 6, Czech Republic \\ apavelholubec@centrum.cz
}

\begin{abstract}
Keywords: city, assemblage, perspectivity, world order, alternative, differentiation, object, line of escape, creature
\end{abstract}

\begin{abstract}
Assemblage thinking is process-based thinking. Understanding cities from this perspective implies searching for processes that are assembling the city and that keeps it alive. Because of this approach, we don't need to ask: „what the city is?" but either: „how did cities emerge?" or: „how is their existence maintained?" The paper argues that the perspective, from which we see cities, matters, because it either highlights or hides something. We will argue, that the result of an object-based thinking about cities, that stems from modern order of the world, is a very finite and constricted notion of a city, that in effect precludes any alternatives. But by overcoming the obsolete notions of objects, objectivity and subjects by notions of assemblage, perspectivity and chaining, the new world order may eventually emerge and resolve also the mounting enviromental and social problems. We understand city as a specific kind of creature that has helped the human society to differentiate and become global. But now is the time to limit the city and this way force the global society to develop itself so it can adapt to the challenges of the Anthropocene.
\end{abstract}

\subsection{Introduction \& methodology}

Since we state that assemblage thinking is process-based thinking, we do not start our inquiry by a definition of either assemblage thinking or of city but by asking: "how to conceive of a city?" What guide us in our task is the method of searching for processes that either hold the assemblage together (processes of maintenance) or for processes by which the assemblage emerge (processes by which something new appear or is being born).

Notice that instead of a term "thing" that our language would automatically suggest in such sentence, we use the term "assemblage". So, what we are doing right from the start is a conscious detour from a conventional mode of thinking. The reason is that assemblage thinking entails divorcing from the concepts of object and objectivity that are heavily implicated in the modern order of the world. So, we have to clearly articulate, that assemblage thinking, as we understand it, implies a strive for a different world order. And that means, in words of Deleuze \& Guattari [1], creating or finding a line of escape from the current order of the world.

\subsection{Preparing the ground: addressing several preliminary questions}

Critique of the modern order of the world. The question that needs to be addressed first, because it motivates our inquiry, is of course: why do we want to change the current order of the world? Isn't it, in the end, the best world possible?

There are at least two long and wide streams of criticism of the arrangement of modern world. One stream springs from Karl Marx and entails critique of capitalism that is focused especially on growing social inequality, resulting in a growing misery of large segments of population, and on alienation of human beings. This stream of thought is usually aware that the solution of perceived problems requires fundamental change of the order of the world, that is, overcoming capitalism.

Second stream of critique comes from various Earth sciences and points to the pollution of the environment, depletion of resources, extinction of species and consequences of climate change [2]. But it seems to us that only recently, with the advent of concept of the Anthropocene [3] and Bruno Latour's politicization of this concept in the image of Humans that are in a war against the Gaia- 
Earth [4], the implications of this critique resulted in awareness that changing the order of the world is a necessary step in turning away from its self-destructive trajectory.

Considering these two broad lines of criticism, the current „modern“ order of the world needs to be changed. However, there are at least three big obstacles, that are protecting the modern world order from any substantial change: individualism that goes hand in hand with certain notion of freedom, and deeply embedded notions of objectivity and objects. We have to release ourselves from the grip of these concepts first.

Against individual freedom. People are born to be conditioned. Because we are so open to the world, capable of learning so wide spectrum of skills, languages and ways of life, we are also quite open, especially as infants, to all kinds of conditioning by society [5]. What do we learn as kids may, therefore, be quite difficult to unlearn later in our life. We are conditioned not only by our family, by places where we grow and by educational system, but also by the overall society and therefore also by the order of the world.

The problem with a concept of individual freedom is that it attributes responsibility solely to the individual and this way neglects the fact that we have only limited chance to choose our social conditions. Luhmann critically says: ,modern values, such as equality and freedom, serve as cover terms to preserve an illusion of innocence-equality as equal opportunity and freedom as allowing for individual (and not societal) attribution." [6]

So, what to do? Although we are not free, the one thing we can do is to release ourselves from the chains of social conditioning and strive to become free: to acknowledge the specific way in which is our perspective framed and this way also find our unique perspective. Because it is only by way of separating that what is a result of social conditioning that our unique perspective, based on our capabilities, experiences and explorations, may emerge and inspire others [5]. Without this deconditioning or unlearning, our perspective or opinion will always be mixed with that what the social system implanted to us. Only freedom that there can be, is by realizing how we are chained and by learning to cope with it.

Against objectivity. Why we are againt the notion of objectivity? Because this notion entails petrification of certain power relations: „our task is to resist the cumulative depoliticization of concepts and the suggestion we are producing impartial information. Instead, we must realize that every truth produced has concrete power effects, and conversely, that we live in regimes of power that regulate what is considered a legitimate process for producing truths, the types of discourse that are capable of being recognized as truth and the status accorded to those who produce them." [7]

What we suggest instead of objectivity is a notion of perspectivity that is: everything in the world is seen from certain perspective. This also means, as the theory of complex self-referential systems is telling us [8], that each pespective, each point of view, has certain blind spot or bias. In other words, because there is no way of perceiving the world "from outside", we are forced to take stances, forced to take sides. There is simply no objective or neutral point of view. Asserting the notion of objectivity is only a practice of power that attempts to hide its working.

Against objects. Objects means things. Object is static, stable, or, in some conceptual extension, in a state of dynamic equilibrium. But life and living creatures are dynamic, changing and far from equilibrium. The problem is, that the notion of object is not compatible with the notion of life because it is hard to explain the existence of life, starting with the concept of "dead" (stable) matter. The other way is quite easy. Processes are, therefore, ontologically preceding things. This conceptual inversion means also a preference of life over death. And we must acknowledge that this is a perspective of a living creature - so, in our inquiry, we are consciously taking the side of living creatures.

This is why we [9] put forward the notion of assemblage, originating from Deleuze [1] and futher elaborated by De Landa [10], that replaces the notion of object. Assemblage is assembled from various elements (often from another assemblages), usually in a complex process of assembly.

Take, for example, the brick: it looks like a simple thing but in fact it implies some people that made it, the concepts of a house, standardization and form, as well as the rather advanced 
technological process of burning. Because the brick is certainly not living, we are going to categorize it as an artifact, that is as a passive assemblage.

On the other hand, the active assemblages are much more interesting, because they entail the processes of positive and negative feedback, self-organization, self-reference or autopoiesis.

\section{How do cities emerge? How is their existence maintained?}

We propose, that cities are the second type of an assemblage and therefore that they are, in their specific way, a kind of living creatures. In contrast, there are also cities that became mere artifacts: destroyed or abandoned cities in deserts and jungles, ghost towns or deserted industrial areas. Interestingly enough, with advent of tourist industry, some cities like this now lives some kind of a second life: the buildings are revived or restored, the place is plugged into infrastructural networks and the whole city is populated by tourists, guides and shopkeepers.

We can see in this example, that an assemblage cannot be defined by any kind of essence [10]. It is all about processes and relations (even relation is a process because relations must be established and then maintained). And the elements, out of which the assemblage emerge, can be assembled differently. Although all the cities consists largely of the same elements: of streets, places and houses, that are put in place and vitalized by flows of people, goods and ideas, the way the people live in each city, or even in the same city, may differ substantially. Just compare the way people lived, what they discussed and what kinds of places and houses were built in Prague during the many social setting or regimes of $20^{\text {th }}$ century. What each succesive regime did, was to rearrange the elements that were already there (who, what kinds of social groups rule the city?), changed some social practices (how are the city plans prepared and realized?), added several new elements (building the metro and big residential areas during the era of communist normalization) or removed some of the existing elements (demolition of Josefov at the turn of the century, displacement of jewish and german population during WW2, demolition of Těšnov railway station in 1985).

What do we propose here in speaking about the city as of a kind of living creature is, that these rearrangments of the elements of a city are not much of the choice of those who ,rule“ or "govern“ the city. Every element is bound in one way or the other by other elements: although city council may decide on masterplan, it may not have resources to realize it; although private investors may have the money and own the property, they are still bounded by legislation, building authority, masterplan, opinions of the neighbours as well as and by the available supply of building materials, mechanization and technologies.

This is what we mean when we say „city decides“ - it is the „decision“ of the assemblage that emerge out of the elements in place: how to relate the elements to each other. For example, the general attitude of motorists to cyclists is not just individual decision of each driver, it is framed also by traffic policy, by affluence of the society, by social significance of car and bike (what kind of status symbol they are) and also by an available street space .

\subsection{Cities as objects: an overwhelming weight of dead matter}

Now we get to the point, where we are going to explain the differences between city conceived either as object, or as an assemblage. And by the way, we will also elucidate several features of the old (modern) order of the world as well as the way the undesirable features can be overcome and the new order of the world may emerge.

The modern order of the world is still hierarchical, although highly functionally differentiated. The most salient example is the way one of the social subsystems - economy - dominates all the other subsystems and that the distinction rich/poor or have/have-not frames most of the other relations. To put it more clealy, we are still living in capitalism and in capitalist cities. And this means that population in a city is distributed predominantly according to the income, which results in fragmented city: "social division in the post-industrial city suggests that it can be carved into distinctive quarters: (a) the luxury city, segregated in enclaves of specific, isolated buildings in the 
city occupied by the economic, social and political elite; (b) the gentrified city, occupied by the professional, managerial and technical social groups; (c) the suburban city, apartments near the city centre or outer city housing, occupied by "mid-range" professionals and civil servants; (d) the tenement city, often occupied by "blue and white collar" workers in the rented sector, which includes social (public) housing; (e) the abandoned city, "the end result of trickle down, left for the poor, the unemployed, the excluded." [11].

Other feature of the modern order of the world is the subjection of population to power. According to Deleuze, only recent change is that discipline, which was a characteristic of industrial modernity, was replaced by controll. While disciplining power controlled our behaviour, controlling power is manipulating our desire [1]. This is expressed in a transformation of the city from a place of production (dominated by work and factories) to the place of consumption (shopping malls, services and omnipresent advertising). In short, cities has became spectacles of its own [12], superficial, tourist attractions and consisting of places "to see" and "not to be seen". Primacy of function was replaced by a primacy of design. However, we should not forget that the function of design is often just to obfuscate power relations. And accompanying feature of this transformation is also enormous level of alienation that goes hand in hand with information warfare.

In the end, what ensures continuance of the modern world order, its self-reference or its reproduction, is its attribution of subjects, objects and a notion of objectivity. While on one hand objects are all the material things, all the world is made of „dead“ objects at disposal, curiously including also human and animal bodies, subjectivity, on the other hand, is attributed only to the human psyche. In this way, our bodies are subjected to our minds and there is a hierarchical relation between them, where mind dominates, moves and rules its object, its body.

But the most peculiar relation is the one where all such designated objects of the world are subjected to the objective world order. Such notion not only de-animates the emergent world order [4] but effectively blocks all the possible lines of escape [1] from it because it convinces us that such world order is necessary and that it was always there. The modern order of the world is therefore maintained by sacrificing its living nature on the altars of ours conditioned minds. And it is the mind that comes out of this operation as ruler. All the other possible worlds are at the same time blocked and killed as infants because in objective world, possible becomes only that what is already realized [12]. This is what we mean by an overwhelming weight of the dead matter.

\subsection{Cities as assemblages: invisible alternatives in becoming}

You want some new world order? Ok, just describe it so it can be assessed beforehand! This is how the guardians of the modern world, quite often distinguished scientists, teachers and critics are defending the status quo. Because, how can be described something emergent? Only things that can be possitively described are seeds of the new and vectors of the lines of escape. And this is the true role of scientists and philosophers: to discover the cracks in reality where can be planted the wild seeds of the new world. As Chatterton et. al. is telling us: „The aim of critical/radical geographers must not be to produce theory compatible with the present; we are not interested in reproducing a knowledge of a 'possible' that is constantly being defined on our behalf. The only knowledge worth producing is that which contributes to the doing of the impossible, of aiding us to do things we are told can't be done or thought." [7]

The difficult thing for modern minds is not trying to change the world because the world order cannot be changed this way, not by way of revolution. It is not that „we make a revolution“ but the other way round: the revolution may eventually take us. Only thing that each one of us can do is to do that what he or she considers to be right from his or hers unique perspective [5] - only this way can the conditions for emergence of something new and desirable be prepared. But only conditions. New world order emerges only when the time is ripe for it.

The task of the teachers is to show us the diversity of the world and support development of everyone's unique perspective. We need to be freed from the homogenized world-view that the 
modern education instilled into us! Only this way the alternatives can be seen and lived: if we unlearn that what we know and start to experiment with our own lives. Everyone is a probe, exploring and experiencing the diversity of all that there is. Our task is to articulate and share our unique perspective, inspire others and support them in their heresies. If we want to bring about something new, we have to try it, experiment and dare to make errors because only this way we may eventually find out what works and what is livable [5].

So, if there is, for example, overuse of our ecological capacity [13], we have to try to diminish our energy use, rework our energy systems to accomodate renewables and remake our transport systems in order to use less cars [14]. If we try this, we can make mistakes but we will be able to learn from them and make it better. There is no point in arguing that changing our energy and transport systems is impossible: the new elements (decentralized wind and solar power plants, passive or energy plus houses, electric cars or bikes) are already there and what is missing is overcoming the institutional obstacles and connecting the dots.

\section{Conclusion}

We may ask in the end: what is the role of cities? Or, how to live with as well as live within such unusual creatures? Hardt and Negri says: ,the city is to the multitude what the factory was to the industrial working class." [15] It is a crucial place for maintenance of modern order of the world, and indeed a place from which it probably emerged [16], but it is also a place of struggle, which produces diverse alternatives and lines of escape.

In this paper we put forward the perspective that the city is a specific kind of a living and evolving creature. What that mean is that our attitude to it should be more of domesticating it, tending it, teaching it and accommodating ourselves to its way of life (where we play a crucial part), rather than looking at it solely as our own creation that entitles us to rule it.

The city is a creature that puts certain limits on us and that forces us to evolve and differentiate. And this is also a way, how to change our cities and societies: to put certain limits on them and then let it evolve and differentiate. Cities and societies would eventually accommodate to them and if the limits are reasonable (substantively rational), it will be for better.

But it must be noted that the question of limits is inherently political and therefore conflictual [17] and that we must take sides [4, 18]. We have to choose, whether we are on the side of modern world order, of abstract capital, centralized power, alienated and homogenized human beings or whether we are on the side of the Earth and whole diversity of living beings, that struggle to find their unique way.

\section{Acknowledgement}

This research has been supported by grant of CTU Prague SGS13/117/OHK1/2T/11 "Changes in the usage of territory and concomitant negative effects II".

\section{References}

[1] G. Deleuze, F. Guattari, Tisíc plošin, Herrman \& synové, Praha, 2010.

[2] IPCC, Summary for Policymakers. In: Climate Change 2013: The Physical Science Basis. Cambridge University Press, Cambridge, United Kingdom and New York, NY, USA, 2013.

[3] J. Zalasiewicz, M. Williams, W. Steffen, P. Crutzen, The New World of the Anthropocene, Environ. Sci. Technol. 44 (2010) 2228-2231.

[4] B. Latour, Facing Gaia: Six lectures on the political theology of nature, 2013, http://www.brunolatour.fr/sites/default/files/downloads/GIFFORD-SIX-LECTURES_1.pdf 
[5] R. U. Hu, Incarnation crosses by profile: an encyclopedia of the costumes of purpose [e-book], International Human Design School, Jovian Archive Corporation, 2008.

[6] N. Luhmann, Globalization or World society: How to conceive of modern society? International Review of Sociology_Revue Internationale de Sociologie, Vol. 7 (1997), No 1, pp. 67-79.

[7] B. Russell, A. Pusey, P. Chatterton, What can an assemblage do?, City 15:5 (2011) 577-583.

[8] N. Luhmann, Social Systems, Stanford University Press, 1995.

[9] P. Holubec, Proces modernity a jeho artikulace v prostorové struktuře území [dizertační práce], Praha 2013.

[10] M. De Landa, A New Philosophy of Society: Assemblage Theory and Social Complexity, Continuum, 2006.

[11] J. V. Beaverstock, J. R. Faulconbridge, M. Hoyler, Capitalism and the City, 2009, http://www.lboro.ac.uk/gawc/rb/rb322.html

[12] G. Debord, Společnost spektáklu, INTU, 2007.

[13] B. Ewing, D. Moore, S. Goldfinger, A. Reed, M. Wackernagel, The Ecological Footprint Atlas 2010. Global Footprint Network, Oakland, 2010.

[14] K. Polanecký, M. Mikeska, M. Sedlák, V. Kotecký, E. Sequens, K. Sutlovičová, J. Jeřábek, J. Hollan, Chytrá energie, Hnutí Duha, Brno-České Budějovice-Praha, 2010.

[15] M. Hardt, A. Negri, Commonwealth, MA: Harvard University Press, Cambridge, 2009.

[16] P. J. Taylor, Extraordinary Cities: Early 'City-ness' and the Invention of Agriculture and States, International Journal of Urban and Regional Research, Volume 36.3, May 2012, pp. 415-47.

[17] C. Schmitt, The Concept of the Political, University of Chicago Press, 1996.

[18] P. Holubec, Cities facing Gaia, in: Urban Environs in the Relation to Sustainable Development Agenda, Czech Technical University in Prague, 2013. 